\title{
Clinicians' Perceptions of Picture Archiving and Communication System (PACS) Use in Patient Care in Eastern Province Hospitals in Saudi Arabia [Corrigendum]
}

\author{
Al-Kahtani N, Al-Dhaif E, Alsaihtati N, Farid K, AlKhater \\ S. J Multidiscip Healthc. 2021;14:743-750.
}

The authors have advised the affiliation list on page 743 is incorrect. The correct author list and affiliation is as follows.

Nouf Al-Kahtani ${ }^{1}$
Esra Al-Dhaif $^{1}$
Noor Alsaihati
Khalid Farid $^{2}$
Suzan AlKhater
${ }^{1}$ Health Information Management and Technology, College of Public Health, Imam Abdulrahman Bin Faisal University, Dammam, Saudi Arabia; ${ }^{2}$ Radiological Science Department, College of Applied Medical Sciences, Imam Abdulrahman Bin Faisal University, Dammam, Saudi Arabia; ${ }^{3}$ Department of Pediatrics, College of Medicine, Imam Abdulrahman Bin Faisal University, Dammam, Saudi Arabia; ${ }^{4}$ Department of Pediatrics, King Fahad Hospital of the University, AlKhobar, Saudi Arabia

\section{Publish your work in this journal}

The Journal of Multidisciplinary Healthcare is an international, peerreviewed open-access journal that aims to represent and publish research in healthcare areas delivered by practitioners of different disciplines. This includes studies and reviews conducted by multidisciplinary teams as well as research which evaluates the results or conduct of such teams or healthcare processes in general. The journal covers a very wide range of areas and welcomes submissions from practitioners at all levels, from all over the world. The manuscript management system is completely online and includes a very quick and fair peer-review system. Visit http://www.dovepress.com/testimonials. php to read real quotes from published authors. 